\title{
PENGARUH WAKTU PERENDAMAN PERASAN JERUK NIPIS (Citrus aurantium) TERHADAP PENURUNAN KADAR FORMALIN PADA UDANG REBON
}

\author{
ROSDIANA MUS $^{1 *}$, SULFIANI $^{1}$, DAN NISFA MUSDALIAH ${ }^{2}$ \\ ${ }^{1}$ DIII Teknologi Laboratorium Medis, Fakultas Teknologi Kesehatan, Universitas Megarezky, \\ Jalan Antang Raya No. 43, Makassar, Indonesia. \\ *alamat email korespondensi: rosdiana.mus@gmail.com
}

\section{Informasi Artikel}

Riwayat Naskah:

Diterima pada 08

September 2021

Diterima setelah

direvisi pada 28

Desember 2021

Diterbitkan pada 31

Desember 2021

Kata Kunci:

Formalin; Jeruk nipis

(Citrus aurantium);

Lama perendaman;

Udang rebon;

Spektrofotometri Uv-

Vis.

Keywords:

Formalin; Lime

(Citrus aurantium);

Long immersion;

Small Shrimp;

Spectrophotometry

Uv-Vis.

Abstrak/Abstract

Formalin sebagai antibacterial agent pada makanan yang mengandung banyak protein. Salah satu makanan yang dicurigai mengandung formalin yaitu udang rebon karena memiliki kandungan protein yang tinggi. Senyawa alami yang dapat menurunkan kadar formalin pada udang seperti senyawa saponin dapat ditemukan dalam jeruk nipis (Citrus aurantium). Tujuan penelitian yaitu menentukan kadar formalin pada udang rebon sebelum dan setelah perendaman dengan perasan jeruk nipis berdasarkan lama perendaman 80, 100, dan 120 menit dan mengetahui pengaruh waktu perendaman untuk menurunkan kadar formalin pada udang rebon. Metode penelitian yaitu metode semi kuantitatif (Strip Formaldehid) dan metode kuantitatif (Spektrofotometri UV-Vis). Hasil dari penelitian ini yaitu pada sampel A1 (80 menit $)=0,0321 \% \mathrm{~b} / \mathrm{v}$, sampel A2 $(100$ menit $)=0,0308 \% \mathrm{~b} / \mathrm{v}$ dan sampel A3 (120 menit $)=$ $0,0298 \% \mathrm{~b} / \mathrm{v}$. Penurunan kadar formalin paling tinggi yaitu pada perendaman selama 120 menit dengan konsentrasi awal yaitu $0,0826 \% \mathrm{~b} / \mathrm{v}$ turun menjadi $0,0298 \% \mathrm{~b} / \mathrm{v}$ setelah perendaman dengan perasan jeruk nipis $6 \%$ dengan penurunan kadar formalin sebanyak $0,0528 \% \mathrm{~b} / \mathrm{v}$. Semakin lama waktu perendaman maka semakin menurun kadar formalin pada udang rebon karena senyawa saponin yang terkandung di dalam jeruk nipis mampu berikatan dengan air dan formalin.

Formalin is antibacterial agent in foods that contain lots of protein. One of the foods thought to contain formaldehyde is small shrimp, a source with high protein content. Natural compounds that can reduce formaldehyde levels in shrimp, such as saponin compounds found in lime (citrus aurantium). This study aims to determine the level of formaldehyde in small shrimp before and after soaking with lime juice based on the length of soaking; 80, 100, and 120 minutes and determine the most effective immersion duration to reduce formaldehyde levels. The method used in this research is the semi-quantitative method (strip formaldehyde) and the quantitative method (UV-Vis spectrophotometry). The results are sample A1 (80 minutes $)=0.0298 \% \mathrm{~b} / \mathrm{v}$, A2 $(100$ minutes $)=0.0308 \% \mathrm{~b} / \mathrm{v}$, and sample A3 $(120$ minutes $)=$ $0.0298 \% \mathrm{~b} / \mathrm{v}$. The highest reduction in formaldehyde levels in immersion for 120 minutes with an initial concentration of $0.0826 \% \mathrm{~b} / \mathrm{v}$ to $0.0298 \% \mathrm{~b} / \mathrm{v}$ and after soaking with $6 \%$ lime juice with a decrease in formalin levels of $0.0528 \% \mathrm{~b} / \mathrm{v}$. The longer the duration of immersion, the higher the formaldehyde levels' reduction in small shrimp because the saponin compounds in a lime bind to water and formalin.
\end{abstract}

\section{PENDAHULUAN}

Bahan tambahan pangan menurut peraturan Badan Pengawasan Obat dan Makanan No 11 Tahun 2019 adalah bahan yang ditambahkan ke dalam pangan untuk mempengaruhi sifat atau bentuk pangan [1]. Bahan tambahan pangan yang ditambahkan pada saat bahan makanan diolah berfungsi meningkatkan kualitas, memberi rasa agar lebih enak, warna yang menarik, memperbaiki tekstur makanan dan agar lebih tahan lama. Penggunaan bahan pengawet terkadang melebihi atau bahkan tidak sesuai dosis yang telah ditetapkan. Bahkan adapula yang menggunakan pengawet yang seharusnya tidak digunakan pada makanan seperti boraks, pewarna sintetik dan formalin [2]. Formalin sering digunakan karena harganya yang murah, dan membuat makanan tidak cepat membusuk [3].

Formalin yaitu sebagai antibacterial agent yang dapat memperlambat aktivitas bakteri pada makanan dengan kandungan protein yang tinggi. Formalin bereaksi dengan protein pada makanan sehingga membuat makanan menjadi tahan lama. Formalin sebenarnya tidak boleh digunakan pada makanan sesuai dengan peraturan Menteri Kesehatan Republik Indonesia Nomor 1168/Menkes/Per/X/1999 tentang bahan tambahan makanan, karena dapat membahayakan kesehatan 
orang yang mengkonsumsinya. Formalin jika masuk ke dalam tubuh manusia bersifat karsiogenik [4]. Efek dari bahan pangan berformalin tidak langsung dirasakan apabila dikonsumsi beberapa kali saja aka tetapi baru bisa terasa beberapa tahun kemudian [5].

Udang rebon merupakan salah satu produk perairan yang sangat melimpah sehingga mudah didapatkan dan harganya yang juga relatif murah dan dijual dalam bentuk kering dan sangat jarang dijual dalam keadaan segar [6]. Meskipun makanan kering lebih tahan lama dari makanan basah. Penggunaan formalin oleh pedagang masih sering digunakan dengan tujuan untuk meningkatan kualitas dan menjadi lebih awet sehingga waktu penyimpanan dapat lebih lama [7].

Udang rebon kering yang dikonsumsi oleh masyarakat pedesaaan terkadang tidak dimasak sebelum dikonsumsi hanya dicuci. Konsumsi formalin baik dalam jangka pendek ataupun jangka panjang dapat menimbulkan gejala seperti rasa pusing, sakit perut, muntah-muntah, batuk, iritasi kulit dan saluran pernapasan serta meningkatkan resiko kanker [8].

Hasil penelitian formalin juga pernah dilakukan oleh Suseno (2021) [9] menujukkan bahwa sampel ikan kering diperoleh di pasar tradisional kota Bogor mengandung formaldehida. Penelitian lainnya oleh Umirestu (2014) [2] pada cumi asin di Pasar Tradisional wilayah Pandeglang dengan adar rata-rata formalin sebesar $0,61 \mathrm{mg} / \mathrm{kg}$.

Penggunaan formalin pada makanan dapat menimbulkan efek akut dan kronik yang bisa menyerang sistem pernapasan, sistem pencernaan dan menimbulkan gejala sakit kepala, hipertensi (tekanan darah tinggi), kejang, tidak sadar atau koma. Selain dari itu, formalin dapat menyebabkan kerusakan hati, jantung, otak, limpa, pankreas, sistem susunan saraf pusat dan ginjal. Bila formalin dikonsumsi jangka panjang dapat menyebakan kanker [10].

Konsumsi formalin dengan dosis tinggi dapat menyebabkan konvulsi (kejang-kejang), hematuria (adanya darah pada urin) dan hematomosis (muntah darah) yang berakhir dengan kematian. Injeksi formalin dengan dosis $100 \mathrm{~g}$ dapat menyebabkan kematian dalam jangka waktu 3 jam [2].

Oleh karena itu, perlu senyawa alami yang dapat menurunkan kadar formalin pada udang seperti senyawa saponin yang berperan sebagai emulgator dan senyawa asam yang dapat mengkatalisis ikatan formalin dan protein. Senyawa saponin ini dapat ditemukan dalam jeruk nipis (Citrus aurantium). Selain itu, jeruk nipis juga mengandung senyawa saponin dan flavonoid yaitu hesperidin (hesperetin 7-rutinosida), tangeretin, naringin, eriocitrin, eriocitrocid [11] .
Saponin pada jeruk nipis berpotensi menurunkan kadar formalin dengan cara perendaman. Reaksi saponin pada jeruk nipis dapat menurunkan kadar formalin dikenal dengan reaksi saponifikasi (proses pembentukan sabun) dimana sabun tersebut termasuk dalam kelompok surfaktan [12].

Hasil dari penelitian Eko dan Rizki (2016) menunjukkan ada pengaruh konsentrasi dan lama waktu perendaman terhadap penurunan kadar formalin pada udang vannami. Hasil menunjukkan rata-rata kadar formalin pada sampel tanpa perendaman jeruk nipis sebesar $7,584 \%$. Sedangkan rata-rata kadar formalin pada sampel dengan perendaman jeruk nipis dengan konsentrasi $7 \%$, 5\%, dan $1 \%$ berturut-turut adalah $0,726 \%$, $0,269 \%$, dan $0,139 \%$. Hasil ini menunjukkan ada pengaruh yang signifikan pada penambahan konsentrasi jeruk nipis terhadap penurunan kadar formalin pada udang vannami [13]. Selain itu, penelitian oleh Handayani dkk (2021) menunjukkan ada engaruh perendaman jeruk nipis terhadap penurunan kadar formalin [14].

Berdasarkan uraian diatas, dilakukan penelitian mengenai pengaruh lama perendaman perasan jeruk nipis terhadap kadar formalin udang rebon menggunakan variasi lama perendaman 80 , 100 dan 120 menit dengan konsentrasi jeruk nipis 6\% menggunakan metode spektrofotometer UVVis.

\section{EKSPERIMEN}

\section{Material}

Bahan yang digunakan untuk penelitian adalah aquades, ammonium asetat, asam asetat glacial, asetil aseton, formalin 37\%, jeruk nipis 6\% dan udang rebon.

\section{Instrumentasi}

Alat yang digunakan pada penelitian ini adalah alat-alat gelas, alumunium foil, blender, masker, mikropipet, neraca analitik, sarung tangan, spektrofotometri uv-vis Orion Aquamate 8000 (Thermo Scientific), tip biru, tip kuning dan waterbath.

\section{Prosedur}

Prosedur penentuan kadar formalin, pengaruh perasan jeruk nipis dan lama perendaman terhadap kadar formalin yang digunakan berdasarkan Novitasari (2016) [13]. 
Pemeriksaan Kadar Formalin dengan Menggunakan Strip (Analisis Semi-Kualitatif)

Pada pemeriksaan semi kuantitatif sampel yang diperoleh dari beberapa daerah di gerus hingga halus dan ditambahkan aquadest untuk mendapatkan filtratnya. Filtrat yang diperoleh dari udang rebon kemudian ditambahkan reagen Countains sodium hidroxyde (Fo-1), di amati perubahan warna yang terjadi pada strip.

Penyiapan Konsentrasi Jeruk Nipis dan Persiapan Sampel Pembuatan Konsentrasi Jeruk Nipis 6\%

Menyiapkan jeruk nipis yang telah dicuci bersih, kulit jeruk nipis dikupas hingga bersih dan diambil dagingnya. Selanjutnya diblender hingga halus, jeruk nipis yang telah dihaluskan, kemudian ditimbang sesuai dengan konsentrasi yang akan dibuat yaitu $6 \mathrm{~g}$, jeruk nipis yang telah ditimbang kemudian dilarutkan dalam labu ukur $100 \mathrm{ml}$ dan dicampur hingga homogen, kemudian disaring dan dimasukkan ke dalam erlenmeyer dan ditutup dengan plastik bening.

\section{Penentuan Panjang Gelombang Maksimum}

Larutan formalin $1 \mathrm{~mL}$ dengan konsentrasi 4 ppm dimasukkan ke dalam tabung reaksi tertutup kemudian ditambahkan air hingga volumenya 10 $\mathrm{mL}$ dan $5 \mathrm{~mL}$ pereaksi Nash lalu panaskan dalam penangas air pada suhu $37^{\circ} \mathrm{C}$ selama 30 menit (Setelah dingin), pindahkan kedalam labu ukur 25 $\mathrm{mL}$ secara kuantitatif, cukupkan volumenya menggunakan air, dikocok hingga homogen lalu amati serapannya pada panjang gelombang 400-500 $\mathrm{nm}$ dengan alat spektrofotometri UV-Vis hingga didapat panjang gelombang maksimum.

\section{Validasi Metode Pembuatan Kurva Kalibrasi}

Larutan formalin $1 \mathrm{~mL}$ dengan konsentrasi 0,1 ppm dimasukkan ke dalam tabung reaksi bertutup. Lalu tambahkan air hingga volumenya 10 $\mathrm{mL}$ dan $5 \mathrm{~mL}$ pereaksi Nash dan panaskan air pada suhu $37^{\circ} \mathrm{C}$ selama 30 menit. Kemudian pindahkan kedalam labu ukur secara kuantitatif (setelah dingin) dan dicukupkan volumenya menggunakan air, kocok hingga homogen lalu lanjutkan dengan mengamati serapannya pada panjang gelombang 400-500 nm dengan alat spektrofotometri UV-Vis. Lakukan cara yang sama untuk konsentrasi $0,5,1$, 2, 4, 8 dan 16 ppm dan buatkan kurva kalibrasi hingga didapat persamaan linier $\mathrm{y}=\mathrm{a}+\mathrm{bx}$.

\section{Persiapan Sampel}

Sampel udang rebon di haluskan dengan cara digerus atau di blender dan ditimbang sebanyak $2 \mathrm{~g}$, ditambahkan aquades $10 \mathrm{ml}$ disaring lalu diambil filtratnya, diperiksa kadar formalinnya menggunakan spektrofometri UV-Vis.

\section{Pengukuran Sampel Sebelum Perendaman dan Setelah Perendaman dengan Jeruk Nipis 6\% (Analisis Kuantitatif)}

Udang rebon yang telah disaring kemudian dikocok sampai homogen, pipet $1 \mathrm{~mL}$ destilat dan dimasukkan ke dalam tabung reaksi bertutup dan ditambahkan air hingga volumenya $10 \mathrm{~mL}$ dan $5 \mathrm{~mL}$ pereaksi Nash, panaskan dalam penangas air pada suhu $37^{\circ} \mathrm{C}$ selama 30 menit dan pindahkan ke dalam labu ukur $25 \mathrm{~mL}$ secara kuantitatif setelah dingin, titepatkan volumenya menggunakan air, lalu di ukur serapannya. Setelah ditemukan kadar formalin pada udang rebon maka sampel udang yang positif mengandung formalin tersebut direndam menggunakan perasan jeruk nipis $6 \%$ dengan variasi lama perendaman 80, 100 dan 120 menit. Setelah direndam maka sampel diangin-anginkan kemudian dihaluskan, ditimbang dan ditambahkan aquades agar dapat disaring untuk diambil filtratnya. Hasil saringannya yang berupa filtrat diambil dicukupkan menjadi $10 \mathrm{ml}$ kemudian ditambahkan pereaksi Nash, dipanaskan, dicukupkan $25 \mathrm{ml}$ dan diukur serapannya dengan menggunakan spektrofotometri UV-Vis.

Hasil uji labolatorium akan disajikan dalam bentuk tabel dan dianalisa secara deskriptif dengan modifikasi rumus penentuan kadar formalin [13]:

Kadar $=\frac{\text { C x V x Fp }}{\text { Bobot Sampel }} \times 100 \%$

Ket :

$\mathrm{C}:$ Kadar Absorbansi sampel $(\mathrm{mg} / \mathrm{L})$

$\mathrm{V}$ : Volume sampel yang diperiksa

Fp : Faktor Pengencer

\section{HASIL DAN PEMBAHASAN}

Udang rebon dipilih sebagai sampel pada penelitian ini karena udang rebon yang banyak dijual di pasar dalam keadaan kering. Penambahan formalin pada udang tidak akan mengubah struktur ataupun warna dan rasa pada udang, sehingga udang yang mengandung formalin tidak bisa dibedakan hanya dari melihat tampilannya saja.

Hasil penelitian pada 8 sampel udang rebon yang dibeli di beberapa pasar dan dibedakan berdasarkan asal sampel. Asal sampel yang diambil diantaranya Pinrang, Pare-pare, Palu, Kendari, 
Barru dan Bone. Hasil dari penelitian yang dilakukan pada udang rebon untuk memeriksa apakah ada kandungan formalin yang terdapat didalamnya maka dilakukan percobaan uji semi kuantitatif menggunakan strip formaldehid. Uji formalin menggunakan strip bertujuan sebagai kontrol apakah pada udang rebon positif atau negatif yang nantinya akan diperiksa kadarnya dengan menggunakan alat spektrofotometri UVVis.

\section{Uji Strip Formalin}

Berdasarkan data pada Tabel 1 dapat menunjukkan pada sampel A di mana terjadi perubahan warna pada strip yang awalnya berwarna putih menjadi warna ungu kecoklatan dengan hasil $40 \mathrm{mg} / \mathrm{L}$. Pada sampel dengan kode B, C, D, E, F, $\mathrm{G}$ dan $\mathrm{H}$ tidak terjadi perubahan warna yang menandakan sampel udang rebon tersebut tidak memiliki kadar formalin $0 \mathrm{mg} / \mathrm{L}$ atau negatif mengandung formalin. berdasarkan hasil dari strip yang menunjukkan warna kuning setelah dicelupkan pada sampel yang berarti hasilnya 0 $\mathrm{mg} / \mathrm{L}$.

Pemeriksaan formalin yang pertama dilakukan yaitu pemeriksaan semi-kuantitatif dengan menggunakan strip formaldehid untuk mengetahui apakah dari semua sampel yang digunakan mengandung formalin atau tidak. Sampel udang digerus hingga halus agar sampel bisa hancur menjadi pertikel-partikel yang lebih kecil dari sebelumnya. Fungsi dari penambahan reagen Countains sodium hidroxyde (Fo-1) akan bereaksi dengan formalin yang terdapat pada sampel yang dianaisa sehingga membentuk senyawa kompleks berwarna. Adapun kekurangan dari pemeriksaan ini yaitu tidak dapat mendeteksi formalin jika kadarnya berada dibawah $10 \mathrm{mg} / \mathrm{L}$.

Proses interpretasi hasil dari uji formalin dengan menggunakan strip formaldehid dengan cara mengamati perubahan warna pada kertas latex kemudian dibandingkan dengan standar warna yang terdapat pada botol strip tes formaldehid. Hasil pada uji strip formaldehid yaitu terjadi perubahan warna dari putih menjadi merah muda hingga coklat tua berdasarkan konsentrasi formalin yang terkandung didalamnya.

Hasil pemeriksaan dengan menggunakan strip formaldehid berdasarkan Tabel 1 didapatkan dari 8 sampel udang rebon yang diperiksa 1 sampel yang positif mengandung formalin yaitu pada sampel A di mana terjadi perubahan warna pada strip dari putih menjadi ungu kecoklatan dengan hasil (+++) 40mg/L.
Tabel 1. Hasil pemeriksaan formalin menggunakan strip formaldehid.

\begin{tabular}{|c|c|c|c|}
\hline No. & Sampel & Pengamatan & Hasil \\
\hline 1 & A & $\begin{array}{lr}\text { Terjadi } & \text { perubahan } \\
\text { warna } & \text { strip } \\
\text { formaldehid } & \text { dari } \\
\text { warna putih } & \text { menjadi } \\
\text { warna } & \text { coklat } \\
\text { keunguan } & \end{array}$ & $(40 \mathrm{mg} / \mathrm{L})$ \\
\hline 2 & $\begin{array}{l}\text { B, C, D, } \\
\text { E, F, G, } \\
\text { dan H }\end{array}$ & $\begin{array}{l}\text { Terjadi perubahan } \\
\text { warna strip tes dari } \\
\text { putih menjadi kuning. }\end{array}$ & $\begin{array}{l}\text { Negatif } \\
0 \mathrm{mg} / \mathrm{L}\end{array}$ \\
\hline
\end{tabular}

\section{Penentuan Panjang Gelombang Maksimum}

Hasil panjang gelombang maksimum dengan absorbansi maksimum didpatkan paling stabil yaitu pada panjang gelombang $420 \mathrm{~nm}$ dengan absorbansi $1,181 \mathrm{ppm}$. Rentan panjang gelombang maksimum pada penelitian ini yang dapat digunakan adalah $400-430 \mathrm{~nm}$ dengan panjang gelmbang paling baik yaitu $420 \mathrm{~nm}$.

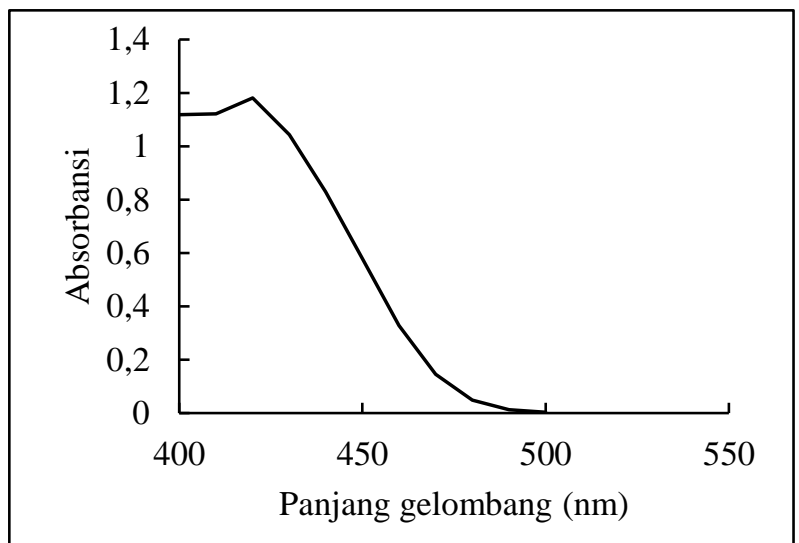

Gambar 1. Kurva panjang gelombang maksimum.

Penetapan panjang gelombang maksimun serta pembuatan kurva kalibrasi dan penepatapan kadar formalin pada udang rebon dilakukan dengan menggunakan spektrofotometri UV-Vis dengan penambahan pereaksi Nash. Spektrofotometri UVVis adalah metode pemeriksaan kuantitatif yang mudah serta mampu membaca konsentrasi formalin pada sampel walaupun dalam jumlah sangat sedikit, dengan sensitivitas yang bagus dalam proses analisis.

Hasil dari penentuan panjang gelombang optimal yang didapatkan serapan paling stabil yaitu dengan absorbansinya 1,181 ppm dengan menggunakan larutan induk formalin $4 \mathrm{ppm}$ yang telah dicampur dengan pereaksi Nash maka didapatkan panjang gelombang maksimum pada panjang gelombang $420 \mathrm{~nm}$. Penentuan panjang gelombang maksimum formalin bertujuan untuk mengetahui daerah maksimum formalin bekerja 
untuk memberiksan warna serapan yang dapat diabsorbsi oleh alat spektrofotometri UV-Vis.

\section{Kurva Kalibrasi}

Hasil kalibrasi yang dilakukan pada spektrofotometri UV-Vis menggunakan panjang gelombang $420 \mathrm{~nm}$ dengan larutan induk berdasarkan konsentrasi yang berbeda-beda maka didapatkan pula hasil absorbansi yang berbeda sesuai dengan konsentrasi larutan induknya. kurva kalibrasi formalin yaitu sebagai berikut (Gambar 2).

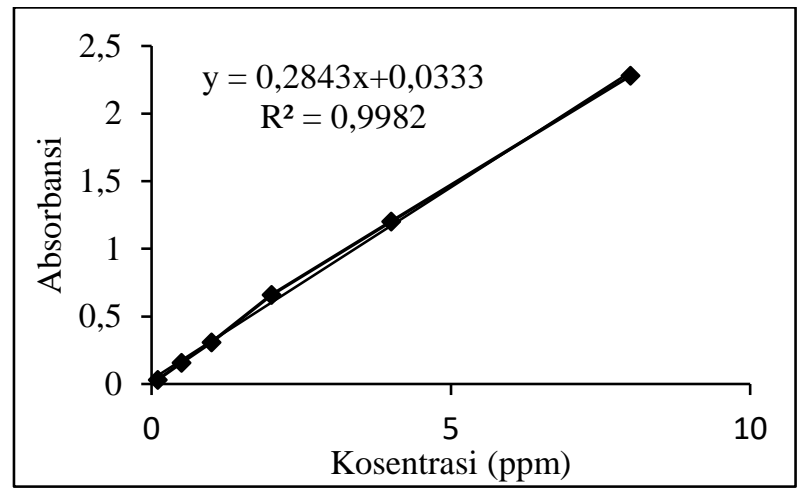

Gambar 2. Kurva kalibrasi formalin.

Kurva Kalibrasi formalin yang dibuat dalam enam konsentrasi formalin yang bertingkat yaitu 0,1 ppm, 0,5 ppm, 1 ppm, 2 ppm, 4 ppm dan 8 ppm (Gambar 2). Berdasarkan nilai absorbansi yang didapatkan menunjukkan bahwa kurva yang dihasilkan meningkat sejajar sesuai dengan peningkatan konsentrasi formalin yang dibuat. Dari hasil absorbansi tersebut maka didapatkan persamaan linear $y=0,283 x+0,0333, R^{2}=0,9982$, dimana hasil persamaan linear tersebut mendekati angka 1 dan apabila nilai linearnya 1 atau mendekati angka 1 maka hasil dari kurva kalibrasi tersebut dapat dikatakan baik karena tingkat kepercayaannya mendekati angka 1. Maka alat spektrofotometri UVVis tersebut siap digunakan untuk menentukan kadar formalin pada udang rebon.

Senyawa yang akan diukur dengan menggunakan spektrofotometri UV-Vis adalah senyawa yang dapat memberikan serapan yaitu senyawa dengan gugus kromofor. Penambahan dengan pereaksi Nash akan merubah larutan menjadi berwarna kuning akibat terhidrolisis kedalam bentuk enol setelah dipanaskan, dan agar dapat memenuhi syarat untuk diukur serapannya dengan menggunakan alat spektrofotometri UV-Vis maka ditambahkan pereaksi Nash pada larutan yang tidak berwarna agar memberikan spektrum serapan yang berwarna pada formalin untuk menghasilkan warna kuning. Semakin kuning warna larutan yang terbentuk maka dicurigai konsentrasi formalin yang terdapat dalam analit juga semakin besar. Formalin yang ditambahkan dengan pereaksi Nash dan dilakukan pemanasan selama 30 menit dengan suhu $37^{\circ} \mathrm{C}$ akan menghasilkan warna kuning, sehingga dapat diukur serapannya menggunkan spektrofotometri sinar tampak.

Penambahan aquades berfungsi untuk mengambil filtrat pada sampel. Filtrat sampel direnasikan dengan pereaksi Nash (Amonium Asetat, Asam Asetat Glacial, dan Asetil Aseton). Homogenkan agar filtrate-air-pereaksi tercampur dan menghasilkan warna yang rata. Kemudian lakukan pemanasan selama 30 menit dengan suhu $37^{\circ} \mathrm{C}$ untuk membentuk warna kuning akibat terhidrolisisnya formalin jika sampel positif formalin. Sampel di ukur pada panjang gelombang 420 menggunakan spektrofotometri UV-Vis, semua sampel diberikan perlakuan yang sama.

\section{Hasil Pemeriksaan Formalin}

Hasil pemeriksaan kadar formalin yang dilakukan pada 8 sampel udang rebon dengan menggunakan spektrofotometri UV-Vis. Maka didapatkan semua sampel positif megandung formalin, tetapi kadar formalin pada setiap sampel memiliki konsentrasi yang berbeda-beda.

Pada sampel A konsentrasi yang terserap yaitu : 6,6107 ppm atau kadar formalinnya 0,0826\% $\mathrm{b} / \mathrm{v}$ pada setiap $2 \mathrm{~g}$ sampel, sampel B : 0,1167 ppm atau $0,0014 \% \mathrm{~b} / \mathrm{v}$, sampel $\mathrm{C}: 0,1096 \mathrm{ppm}$ atau $0,0013 \% \mathrm{~b} / \mathrm{v}$, sampel D : $0,1770 \mathrm{ppm}$ atau $0,0022 \%$ $\mathrm{b} / \mathrm{v}$, sampel E : 0,5709 ppm atau $0,0071 \% \mathrm{~b} / \mathrm{v}$, sampel F : 0,4325 ppm atau $0,0054 \% \mathrm{~b} / \mathrm{v}$, sampel G : 0,0571 ppm atau 0,0007 b/v dan sampel $\mathrm{H}: 0,6135$ ppm atau 0,0076\% b/v dalam $2 \mathrm{~g}$ sampel udang rebon. Diagram hasil penetapan formalin pada udang rebon (Gambar 3).

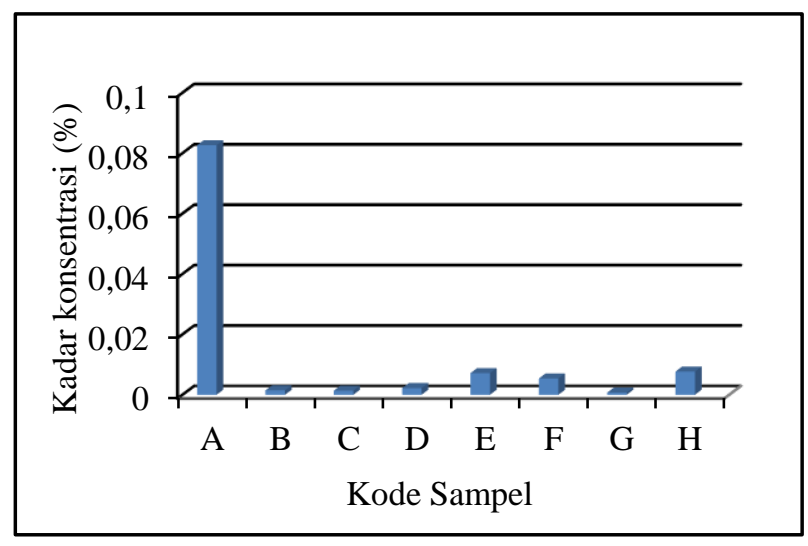

Gambar 3. Hasil pemeriksaan kadar formalin pada udang rebon.

Hasil pemeriksaan yang didapatkan dalam bentuk diagram menunjukkan konsentrasi kadar formalin pada setiap $2 \mathrm{~g}$ udang rebon yang telah 
dihaluskan. Maka dapat disimpulkan bahwa sampel dengan konsentrasi tertinggi terdapat pada sampel A dan sampel dengan konsentrasi terendah yaitu pada sampel G.

Hasil yang diperoleh dari penelitian ini dari 8 sampel yang diperiksa dengan menggunakan spektrofotometri UV-Vis semuanya mengandung formalin dengan konsentrasi yang berbeda-beda dengan nilai tertinggi absorbannya yaitu pada sampel $\mathrm{A}=6.61071682 \mathrm{ppm}$ dan kadar paling rendah absorbannya yaitu sampel $\mathrm{G}=0,05713272$ ppm. Makanan yang mengandung protein jika ditambahkan formalin maka gugus aldehida didalam formaldehid akan mengikat unsur protein. Protein yang terikat tersebut tidak bisa digunakan oleh bakteri pembusuk, sehingga makanan yang mengandung formalin tahan lebih lama. Selain itu, protein dengan struktur senyawa methylene tidak dapat dicerna [15].

\section{Hasil Penurunan Kadar Formalin setelah Perendaman Dengan Perasan Jeruk Nipis 6\%}

Sampel A digunakan sebagai sampel perendaman perasan jeruk nipis $6 \%$ dari 8 sampel keseluruhan untuk melihat pengaruh penurunan kadar formalinnya. Setelah dilakukan perendaman. Sampel A direndam dengan menggunakan perasan jeruk nipis $6 \%$ dengan variasi lama waktu perendaman yaitu 80 menit, 100 menit dan 120 menit. Perendaman dengan jeruk nipis bertujuan untuk menurunkan kadar formalin karena zat aktif saponin mampu mengikat formalin. Hasil pemeriksaan formalin pada udang rebon yang telah direndam kemudian diukur dengan menggunakan metode spektrofotometri UV-Vis didapatkan penurunan kadar formalin seperti pada Tabel 2.

Tabel 2. Hasil penurunan kadar formalin setelah perendaman.

\begin{tabular}{cccc}
\hline $\begin{array}{c}\text { Waktu } \\
\text { Perendaman }\end{array}$ & Absorbansi & $\begin{array}{c}\text { Konsentrasi } \\
(\mathrm{ppm})\end{array}$ & $\begin{array}{c}\text { Kadar } \\
(\% \mathrm{~b} / \mathrm{v})\end{array}$ \\
\hline $\begin{array}{c}\text { Udang Rebon } \\
\text { positif/ } \\
\text { Kontrol (A) }\end{array}$ & 1,91 & 6,6107 & 0,0826 \\
80 menit (A1) & 0,772 & 2,5723 & 0,0321 \\
$\begin{array}{c}100 \text { menit } \\
(\mathrm{A} 2)\end{array}$ & 0,742 & 2,4659 & 0,0308 \\
$\begin{array}{c}120 \text { menit } \\
(\mathrm{A} 3)\end{array}$ & 0,72 & 2,3878 & 0,0298 \\
\hline
\end{tabular}

Pada Tabel 2 menunjukkan bahwa kadar formalin pada sampel A sebelum dilakukan perendaman dengan perasan jeruk nipis didapatkan kadar formalin yaitu $6,6107 \mathrm{ppm}$ atau $0,0826 \% \mathrm{~b} / \mathrm{v}$ pada setiap 2 gramnya. Sedangkan setelah dilakukan perendaman dengan menggunakan person jeruk nipis $6 \%$ terjadi penurunan kadar formalin yang terdapat pada sampel A yaitu pada sampel A1 (80 menit) $=2,5723$ ppm atau $0,0321 \%$ $\mathrm{b} / \mathrm{v}$, sampel A2 (100 menit) $=2,4659 \mathrm{ppm}$ atau $0,0308 \% \mathrm{~b} / \mathrm{v}$ dan sampel A3 (120 menit) $=2,3878$ $\mathrm{ppm}$ atau $0,0298 \% \mathrm{~b} / \mathrm{v}$. Penurunan sebelum dan setelah perendaman dengan perasan jeruk nipis tertinggi pada sampel A3 dengan waktu perendaman 120 menit . Untuk melihat penurunan kadar formalinnya maka perhatikan kurva dibawah ini.

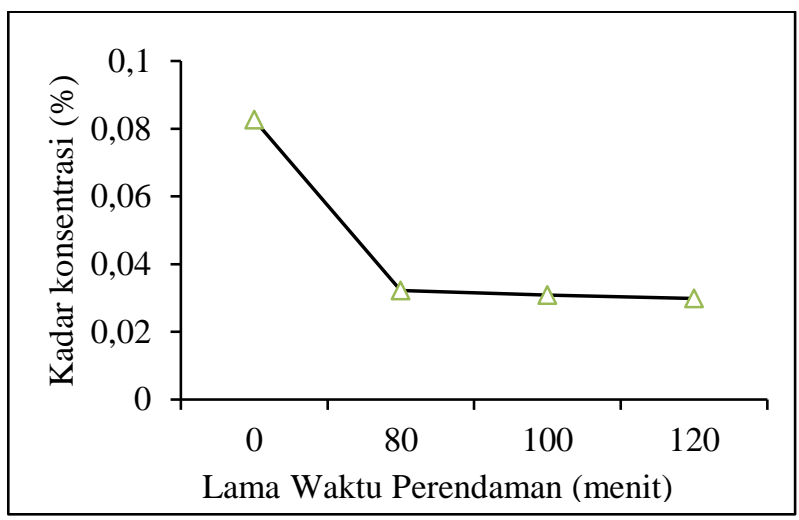

Gambar 4. Kurva penurunan kadar formalin sebelum dan setelah perendaman.

Berdasarkan Gambar 4 menunjukkan bahwa terjadi penurunan setelah perendaman dengan perasan jeruk nipis 6\%. Maka untuk melihat apakah perendaman jeruk nipis $6 \%$ tersebut berpengaruh dalam penurunan formalin pada udang rebon yang dihitung dengan rumus anova dimana jika nilai $P$ value lebih kecil dari nilai $\alpha(0,05)$, maka $\mathrm{H}_{1}$ diterima dan Ho ditolak, artinya terdapat pengaruh yang nyata lama perendaman dengan perasan jeruk nipis 6\% terhadap penurunan kadar formalin. Sedangkan jika $P$-value lebih besar dari nilai $\alpha$ $(0,05)$, maka $\mathrm{H}_{1}$ ditolak dan Ho diterima, artinya tidak terdapat pengaruh penurunan yang nyata antara lama perendaman perasan jeruk nipis $6 \%$ terhadap penurunan kadar formalin.

Hasil yang didapatkan dari penurunan kadar formalin yaitu paling signifikan pada perendaman selama 120 menit dengan jeruk nipis $6 \%$ dari 6,6107 ppm menjadi 2,3878 ppm dengan penurunan 4,2228 dengan kadar rata-rata penurunan formalin yaitu $66 \%$. Hal ini dapat terjadi karena senyawa saponin yang terkandung di dalam jeruk nipis mampu berikatan dengan air dan formalin. Senyawa saponin memiliki 2 gugus, dari kedua gugus yaitu polar dan nonpolar yang memiliki kemampuan mengemulsi air dan formalin, formalin (polar) sedangkan ekor bersifat nonpolar [16]. Senyawa saponin merupakan senyawa glikosida kompleks 
yaitu terdiri dari senyawa hasil kondensasi suatu gula dengan suatu senyawa hidroksil organik yang apabila dihidrolisis akan menghasilkan gula (glikon) dan non-gula (aglikon) [17]. Bagian glikon terdiri dari gugus gula seperti glukosa, fruktosa dan jenis gula lainnya. Sedangkan bagian aglikon merupakan sapogenin. Sifat ampifilik ini dapat membuat bahan alam yang mengandung saponin bisa berfungsi sebagai surfaktan [18]. Saponin memiliki beberapa fungsi biologis seperti antioksidan, imunostimulan, antihepatoksik, antibakteri, antikarsinogenik, antihipoglikemik, dan antimolluscicidal [19] [20].

\section{SIMPULAN}

Penelitian ini didapatkan hasil bahwa perasan jeruk nipis $6 \%$ berpengaruh untuk menurunkan kadar formalin pada udang rebon setelah perendaman dengan perasan jeruk nipis $6 \%$. Penurunan kadar formalin paling tinggi yaitu pada perendaman selama 120 menit atau 2 jam dengan menurunanan mencapai 4, 2229 ppm. Karena semakin lama waktu perendaman maka semakin penurun pula kadar formalin yang terkandung dalam udang rebon.

\section{UCAPAN TERIMA KASIH}

Terima kasih kepada Laboratorium Kimia Prodi DIII TLM Universitas Mega Rezky dan laboratorium Maritim Jurusan Teknik Kimia Politeknik Negeri Ujung Pandang yang telah membantu dalam proses penelitian.

\section{REFERENSI}

[1] Peraturan Badan Pengawasan Obat dan Makanan, "Bahan Tambahan Makanan No. 11 Tahun 2019", BPOM RI, 2019.

[2] C.U. Nurdiani and E. Sriwiditriani, "Analisis formalin pada cumi asin yang dijual di pasar tradisional wilayah pandeglang dengan menggunakan metode spektrofotometri", Anakes: Jurnal Ilmiah Analis Kesehatan, vol. 7, no. 2, pp. 217-225, 2021.

[3] Q.A. Lathifah, D.D.R. Turista, L. Azizah, and A.E. Khulaifi, "Identification of formalin and borax on tuna in Ngemplak market Tulungagung regency", Medical Laboratory Analysis and Sciences Journal (Melysa), vol. 1, no. 1, pp. 1-5, 2019.

[4] O. Hermawan, A.T. Mukti, and M. Yasin, "Formaldehide content in white shrimp after formalin soaking with different doses", Journal of Aquaculture and Fish Health, vol. 9, no. 1, pp. 69-74, 2020.
[5] A.P. Roswiem and T. Septia, "Identifikasi formaldehida dalam tahu dan mie basah pada produk pedagang jajanan di sekitar kampus Universitas YARSI Jakarta", Jurnal Kedokteran Yarsi, vol. 26, no. 3, pp. 112-118, 2018.

[6] A.R. Fatty, "Pengaruh penambahan udang rebon terhadap kandungan gizi dan hasil uji hedonik pada bola-bola tempe", Universitas Indonesia: Depok, 2012.

[7] T.M. Sari, Dira, and Shinta, "Analisis formalin pada ikan asin kembung di beberapa pasar di Kota Padang dengan metoda spektrofotometer Uv-Vis, UNES: Journal of Scientech Research, vol. 2, no. 2, pp. 159-166, 2017.

[8] E.S.T. Suci, "Gambaran perilaku jajan murid sekolah dasar di Jakarta", Psikobuana, vol. 1, no. 1, pp. 29-38, 2009

[9] D. Suseno, "Validasi metode analisis formalin dan aplikasinya pada ikan asin", Jurnal Agroindustri Halal, vol. 7, no. 2, pp. 173-182, 2021.

[10] B. Zakaria, T. Sulastri, and Sudding, "Analisis kandungan formalin pada ikan asin katamba (Lethrinus lentjan) yang beredar di Kota Makassar", Chemica: Jurnal Ilmiah Kimia dan Pendidikan Kimia., vol. 15, no. 2, pp. 16-23, 2014.

[11] Z. Adindaputri, N. Purwanti, and I.A. Wahyudi, "Pengaruh ekstrak kulit jeruk nipis (Citrus aurantifolia swingle) konsentrasi 10\% terhadap aktivitas enzim Glukosiltransferase streptococcus mutans", Majalah Kedokteran Gigi Indonesia, vol. 20, no. 2, pp. 126-13, 2013

[12] A. Gusviputri, N.P.S. Meliana, Aylianawati, And N. Indraswati, "Pembuatan sabun dengan lidah buaya (Aloe vera) sebagai antiseptik alami", Jurnal Ilmiah Widya Teknik, vol. 12, no. 1, pp. 11-21, 2013.

[13] A.E. Novitasari and Rizki, "Pengaruh penambahan konsentrasi jeruk nipis (Citrusaurantifolia s.) terhadap penurunan kadar formalinpada udang vannami (Letapenaeus vannamei) dengan spektrofotometer visible", Jurnal Sains, vol. 6, no. 11, pp. 7-14, 2016.

[14] A.H. Burhan, F. Nurhaeni, Y.P. Rini, F.C. Wulandari, and A.Y.A. Putra, "Efektivitas suhu perendaman sari nanas dan jeruk nipis terhadap penurunan kadar formalin dalam ikan asin teri nasi", Jurnal Ilmu Kesehatan Bhakti Setya Medika, vol. 6, no. 2, pp. 92-99, 2021.

[15] S. Purawisastra and E. Sahara, "Penyerapan formalin oleh beberapa jenis bahan makanan serta penghilangannya melalui perendaman 
dalam air panas", Penelitian Gizi dan Makanan (The Journal of Nutrition and Food Research), vol. 34, no. 1, pp. 63-74, 2011.

[16] A.M. Jannah, A.M. Legowo, Y.B. Pramono, A.N. Al-Baarri, and S.B.M. Abdullah, "Total bakteri asam laktat, $\mathrm{pH}$, keasaman, citarasa, dan kesukaan yoghourt drink dengan penambahan ekstrak buah belimbing", Jurnal Aplikassi Teknologi Pangan, vol. 3, no. 2, 711, 2014.

[17] A.M. Ibrahim, A. Bintoro, and B. Situmeang, "Analisis dan identifikasi senyawa saponin dari daun bidara (Zhizipus mauritania L.)", Jurnal ITEKIMA, vol. 2, no. 1, pp. 84-94, 2017.

[18] F. Nurzaman, J. Djajadisastra, and B. Elya, "Identifikasi kandungan saponin dalam ekstrak kamboja merah (Plumeria rubra L.) dan daya surfaktan dalam sediaan kosmetik", Jurnal Kefarmasian Indonesia, vol. 8, no, 2, pp. 8593, 2018.
[19] M.M.A. El-Aziz and H.A. Madbouly, "Investigations on green preparation of heavy metal saponin complexe", Journal of Water and Environmental Nanotechnology, vol. 2, no. 2, pp. 103-111. 2017.

[20] A.U. Zagel, S. Tajo S., and M. Ali, "Antibacterial activity of citrus aurantifolia leaves extracts against some enteric bacteria of public health importance", Modern Approaches on Material Science", vol. 1, no. 2, pp. 33-38, 2018. 